\title{
AIR QUALITY IN MINING AREAS: THE CASE OF STRATONI, CHALKIDIKI, GREECE
}

\author{
Papastamatiou D., Skarpelis N. and Argyraki A. ${ }^{1}$ \\ ${ }^{1}$ National and Kapodistrian University of Athens, Faculty of Geology and Geoenvironment, Department of \\ Economic Geology and Geochemistry, 15784 Zografou, Athens, Greece, \\ depapasta@hotmail.com,skarpelis@geol.uoa.gr,argyraki@geol.uoa.gr
}

\begin{abstract}
Air quality sampling tests are conducted on a 24 h basis by "HELLENIC GOLD S.A." in the Stratoni mining settlement. The settlement is located in the neighbourhood of a flotation plant where galena and sphalerite concentrates are produced after crushing and processing of $P b-A g$-Zn sulfide ore. Old piles of mineral waste occur close to the settlement. The mineralogy of mineral dust collected on filters of 3 air samplers from August to December 2008 was studied. Elemental analysis of mineral dust collected from January to December 2008 was conducted. The purpose of the study was to determine levels of air pollution, type of mineral particles as well as potential sources. Measurements of air quality included $P M_{10}$. Statistical analysis of the collected data included tests to determine the control on daily particle concentration and mineralogy of fluctuations of temperature, humidity, wind direction and wind speed. Air quality was better than during 1998-2000. Air quality was typically at its worse during hot summer days when wind speed was high. The concentration of $P M_{10}$ particulate matter was quite low when compared to International Air Quality Standards regulations, indicating that levels of air pollution in the area do not pose human health hazards.
\end{abstract}

Key words: air quality, mineral dust, $P M_{10}$, Stratoni, Chalkidiki, Greece.

\section{Introduction}

Protection of public welfare from particulate matter in the atmosphere is promulgated by the Greek law and is being monitored by competent agencies based on international air quality standards. Particulate matter is a significant category of pollution with a variety of shapes and sizes, coming from the processing of materials, procedures of combustion and transformation reactions of gas (Cooper \& Alley, 2004). Historically, particulate matter (PM) measurements have focused on Total Suspended Particulates (TSP). Last decade the primary air quality standard TSP was replaced with PM $_{10}$ standard. $\mathrm{PM}_{10}$ denotes particulate matter which passes through a size-selective inlet as defined in the reference method for sampling and measurement of $\mathrm{PM}_{10} \mathrm{EN} 12341$, with a $50 \%$ efficiency cutoff at $10 \mu \mathrm{m}$ aerodynamic diameter (Directive 2008/50/EC). Recent trends lead to further replacement of $\mathrm{PM}_{10}$ by a $\mathrm{PM}_{2.5}$ standard. Areas in the country with potential for high levels of mineral particulate matter are those where mining, transportation, deposition, crushing-milling and processing of minerals were conducted (e.g. the Florina - Ptolemais - Kozani lignite basins (Triantafyllou, 2000; Triantafyllou et al., 2000) and Lavrion (Skarpelis et al., 2009).

The examination of the amount and type of the particulate matter is imposed especially in areas 


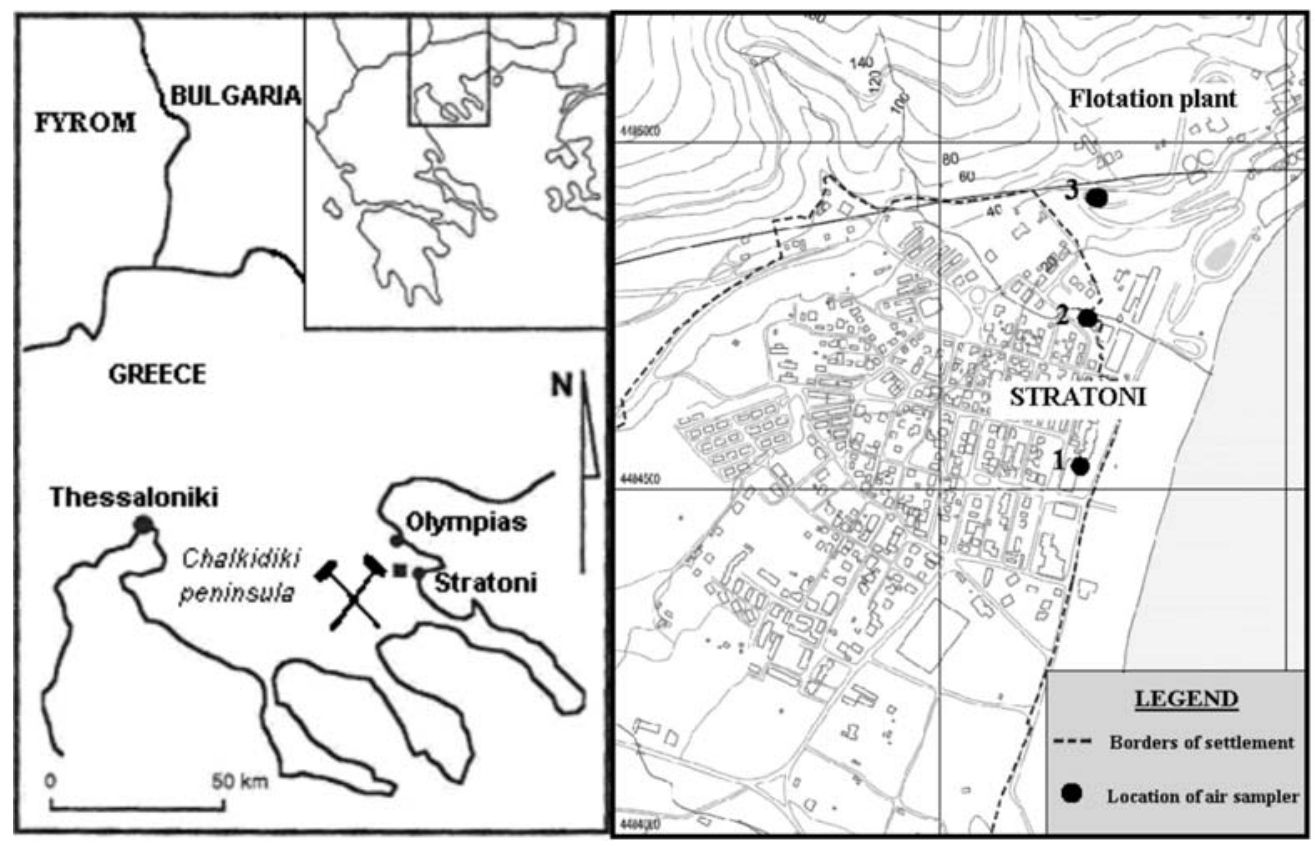

Fig. 1: a: Location of the main mining centers in NE Chalkidiki. b: Location of air samplers. (Ballas \& Gazea, 2009).

where grains of minerals with toxic elements load are released by human activities. The mineralogy, chemistry, solubility and oxidation state of the inhaled particles strongly influence human health effects (Posfai \& Molnar, 2000; Plumlee et al., 2006).

The wider area that Stratoni settlement belongs to, is well known as "Kassandra Mines" (Fig. 1a). The flotation plant of the mining company "HELLENIC GOLD S.A." is located at the northeastern part of the Stratoni settlement, producing sphalerite and galena concentrates after processing of $\mathrm{Pb}-\mathrm{Ag}$ Zn sulphide ore exploited at the Mavres Petres mine. A crushing-milling facility and condensationfiltration and mineral waste units are associated with the flotation plant. For the protection of the citizens and workers welfare of Stratoni, the company has established and operates three air samplers; location of the samplers is shown in Fig. 1b. Previous studies reported on ambient concentrations of Total Suspended Particulate Matter (TSP) in the wider area of Stratoni (Gaidajis, 2003).

The purpose of this study is to identify the mineral phases of $\mathrm{PM}_{10}$ fraction of the dust and search for the source(s) of grains, taking into consideration the chemistry of dust samples and meteorological parameters. Also, there was an evaluation of the impact on air quality at the Stratoni settlement and the data was compared with the conditions during 1998-2000. This data can be used for further assessments of particles dissemination.

\section{Geology of the ore deposits}

The Kassandra mining district comprises mainly $\mathrm{Pb}-\mathrm{Zn}(\mathrm{Ag}-\mathrm{Au})$ carbonate hosted replacement, skarn and porphyry $\mathrm{Cu}-\mathrm{Au}$ ore deposits. They are hosted by lithologies of the Serbomacedonian Belt and temporally and spatially related to Tertiary intrusives. The Mavres Petres, Madem Lakkos and Stratoniki deposits are structurally controlled by the NW-SE trending Varvara - Stratoni fault and litho- 
logically by marble in contact with gneiss of the polymetamorphic Vertiskos Unit. Base metal sulphides, sulphosalts, quartz, rhodochrosite, graphite, kaolinite, sericite are the predominant hypogene minerals (Nikolaou, 1960; Kockel et al., 1977; Nebel et al., 1991; Gilg, 1993; Gilg \& Frei, 1994).

\section{Materials and Methods}

In order to monitor the ambient air quality at Stratoni, air samplers produced by "Thermo Electron" are used (type rp Patrisol -plus model 2025 sequential air sampler). The filters that are used (Pallflex TX40) retain particles $\mathrm{PM}_{10}$, have a diameter of $47 \mathrm{~mm}$ and are made of glass fiber coated with Teflon and manufactured by Thermo Electron 9. Estimation of the index "Mass Concentration", indicating the amount of dust deposited on the filter, was made using the formula: $\mathrm{MC}=\mathrm{DW} 10^{6} / \mathrm{V}$, where: MC: Mass Concentration, DW: mass concentration in grams $(\mathrm{g})$ on the surface of the filter and $\mathrm{V}$ : volume of air (in $\mathrm{m}^{3}$ ) that passed through the filter. Elemental analysis of collected $\mathrm{PM}_{10}$ for $\mathrm{Pb}, \mathrm{Zn}, \mathrm{As}, \mathrm{Cd}, \mathrm{Fe}, \mathrm{Cu}, \mathrm{Mn}$, was performed using Inductively Coupled Plasma - Atomic Emission Spectrometry at the laboratories of «HELLENIC GOLD S.A.».

Mineral investigation was carried out with the aid of a reflected light microscope and a JEOL JSM 5600 Scanning Electron Microscope at the Faculty of Geology and Geoenvironment, University of Athens. Mineral examination was conducted on 61 filters, which were chosen based on their high values of mass concentration. Approximately two filters per week were investigated for a six-month period. The mineralogical composition of samples of mineral waste and tailing, stockpiled sulphide ore and dust from the crushing-milling facility, has been also investigated. Emphasis was given on mineral grains of a size $<10 \mu \mathrm{m}$.

\section{Results and Discussion}

Based on the measurements of the mass concentration for the year 2008, it is presumed that there is a wide range of values between 2.5 and $79.6 \mu \mathrm{g} / \mathrm{m}^{3}$ (Table 1).

Although the mass concentration data (Tables 1,2) refer to $\mathrm{PM}_{10}$ and TSP respectively, a trend for reduction of emission of mineral particulates from the time period of 1998-2000 to 2008 is evident. It is worth mentioning that the ratio $\mathrm{PM}_{10} / \mathrm{TSP}$ is not known; however the mineralogical study of TSP dust collected on the filter of a portable dust sampler during this sampling survey indicates the ratio $\mathrm{PM}_{10} / \mathrm{TSP}$ is roughly around 0.7 .

According to data on Table 1, during 2008, the number of days when mass concentration exceeded the daily limit value of $50 \mu \mathrm{g} / \mathrm{m}^{3}$, were seven (7) in air sampler SAM 1, two (2) in the air sampler SAM 2 and nineteen (19) in the air sampler SAM 3, indicating that the daily concentration of particulate matter of $\mathrm{PM}_{10}$ was quite low when compared to European and International Air Quality Standards. It is worth mentioning - although not directly comparable - that many European cities (e.g. Berlin) cannot comply with the daily limit value for $\mathrm{PM}_{10}$, which is in force since 2005 . As stated by Goergen and Lambrecht (2007) Berlin experienced particle episodes in February, March and October during the year 2005 with $\mathrm{PM}_{10}$ concentrations up to $130 \mu \mathrm{g} / \mathrm{m}^{3}$ in two sites, one close to a very busy street downtown and the other at the periphery of the city.

It is noticeable that mass concentration is not always analogous with the amount of mineral grains. This fact can be explained because organic substances from oil combustion as well as particles of biological origin can settle on the surface of the filter.

The examination of the mineralogy of the dust settled on the filters of the air samplers SAM 1-3, 
showed that grains of pyrite, galena and sphalerite predominate. At a lower proportion, grains of arsenopyrite, chalcopyrite, barite, cerrusite, gypsum, goethite, tennantite, boulanzerite and bournotite can be found (Fig. 2a,b and 3b). Furthermore, in some of the filters, grains of halite were identified (Fig. 3a).

Sphalerite, pyrite, galena and arsenopyrite are the predominant minerals in samples collected from mine waste and tailing piles at the vicinity of the processing plant. Minor mineral constituents are gangue minerals (e.g. quartz, sericite, kaolinite). Samples of dust collected within the area of the crushing -milling facility comprise grains of sphalerite, galena and pyrite. Calcite, quartz and feldspars are subordinate.

Table 1. Mass Concentration variation of PM10 dust at Stratoni from January to December 2008.

SAM 1 to SAM 3: Air samplers; Mass Concentration in $\mu \mathrm{g} / \mathrm{m}^{3}$; NED: Number of Exceedance of regulatory limit Days (35 per year are permitted)

\begin{tabular}{|c|c|c|c|c|c|c|c|c|c|c|c|c|c|c|}
\hline Month & 1 & 2 & 3 & 4 & 5 & 6 & 7 & 8 & 9 & 10 & 11 & 12 & Annual & NED \\
\hline \multicolumn{15}{|c|}{ SAM 1} \\
\hline $\min$ & 8.9 & 18 & 5.4 & 8.7 & 8.3 & 7.1 & 8.7 & 18 & 12 & 10 & 5 & 2.5 & 2.5 & \multirow{4}{*}{7} \\
\hline $\max$ & 38 & 71 & 53 & 64 & 32 & 38 & 29 & 53 & 38 & 50 & 52 & 46 & 70.8 & \\
\hline average & 26 & 33 & 30 & 28 & 17 & 20 & 19 & 31 & 25 & 27 & 24 & 21 & 24.6 & \\
\hline median & 28 & 30 & 28 & 25 & 17 & 20 & 19 & 30 & 23 & 26 & 22 & 17 & 22.5 & \\
\hline \multicolumn{15}{|c|}{ SAM 2} \\
\hline $\min$ & 13 & 20 & 12 & 19 & 11 & 10 & 15 & 13 & 16 & 7.5 & 9.1 & 3.3 & 3.3 & \multirow{4}{*}{2} \\
\hline $\max$ & 27 & 48 & 64 & 29 & 42 & 37 & 27 & 50 & 44 & 52 & 49 & 36 & 63.5 & \\
\hline average & 19 & 29 & 29 & 24 & 22 & 21 & 20 & 34 & 29 & 27 & 24 & 16 & 24.8 & \\
\hline median & 18 & 27 & 29 & 23 & 21 & 19 & 20 & 37 & 29 & 29 & 20 & 15 & 23.6 & \\
\hline \multicolumn{15}{|c|}{ SAM 3} \\
\hline $\min$ & 7.6 & 19 & 12 & 9.6 & 5 & 11 & 15 & 20 & 6.2 & 12 & 3.8 & 6.7 & 3.8 & \multirow{4}{*}{19} \\
\hline $\max$ & 34 & 55 & 60 & 80 & 75 & 61 & 75 & 63 & 52 & 48 & 46 & 67 & 79.6 & \\
\hline average & 22 & 35 & 33 & 34 & 33 & 33 & 35 & 35 & 28 & 27 & 30 & 23 & 30.1 & \\
\hline median & 20 & 35 & 35 & 30 & 31 & 32 & 31 & 35 & 27 & 27 & 22 & 20 & 27.1 & \\
\hline
\end{tabular}

Table2. Mass concentration of Total Suspended Particulate matter from 1998 to 2000 (Gaidajis, 2003).

\begin{tabular}{|c|c|c|c|c|c|}
\hline & \multicolumn{5}{|c|}{ Mass concentration $\left(\boldsymbol{\mu g} / \mathbf{m}^{3}\right)$} \\
\hline Sampler & Number of samples & $\max$ & $\min$ & average & median \\
\hline SAM 1 & 20 & 100.4 & 19.1 & 51.4 & 54.9 \\
\hline A* & 13 & 106.6 & 23.2 & 60.1 & 57.1 \\
\hline B** & 14 & 185.4 & 4.8 & 56.3 & 39.6 \\
\hline
\end{tabular}

* Sampler close to fuel tanks; ** Sampler close to adit +410 

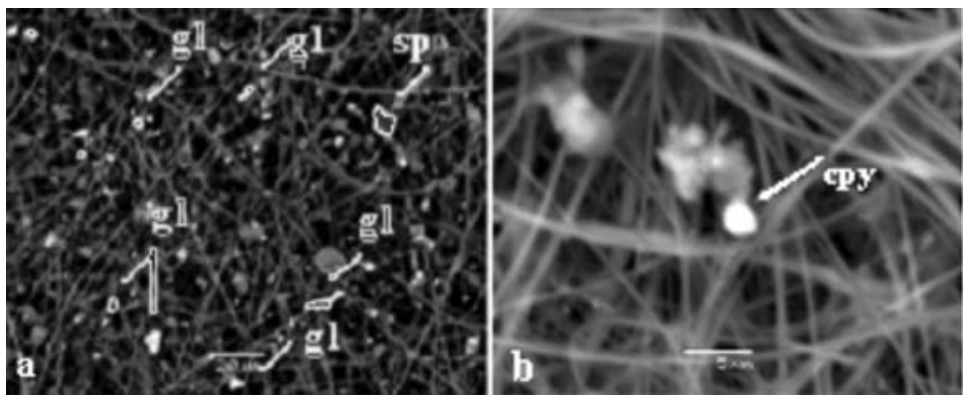

Fig. 2: SEM micrograph of dust grains on air filters: a. "SAM 3 14/9-15/9", b. "SAM 2 30/9-1/10" (gl: galena, sp: sphalerite, cpy: chalcopyrite).

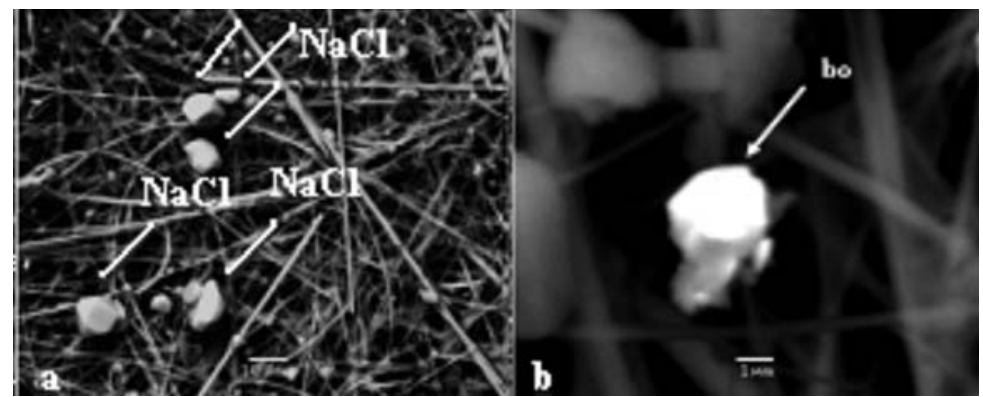

Fig. 3: SEM migrograph of dust grains on air filters: a. "SAM3 14/9-15/9", b. "SAM3 25/11-26/11" (NaCl: halite, bo: bournonite).

Lead concentration in particulate matter during 2008 can be seen in Table 3 . The $\mathrm{Pb}$ values are lower than the permitted limit (annual value $0.5 \mu \mathrm{g} / \mathrm{m}^{3}$; Directive EE 2008/50). It is well-known that due to differential toxicity, various minerals have different impact on human health when inhaled. According to Plumlee et al. (2006), Pb as a constituent of cerussite (a very acid-soluble lead carbonate), $\mathrm{Pb}$ oxides, and $\mathrm{Pb}$ sorbed onto atmospheric aerosols generated by lead-zinc smelting is substantially more bioaccessible than $\mathrm{Pb}$ as a major constituent of galena and various lead-phosphate minerals. Consequently, the dominant presence of galena in the dust acts more positively for the environment rather than other $\mathrm{Pb}$-minerals.

The average concentration of $\mathrm{Fe}, \mathrm{As}, \mathrm{Zn}, \mathrm{Cu}, \mathrm{Mn}$ and $\mathrm{Cd}$ in particulate matter $\mathrm{PM}_{10}$ from all air samplers during 2008 is shown in Table 4, whereas the average concentrations of these metals for TSP during 1998-2000 in Table 5. By comparing these concentrations we cannot observe any significant differences. An exception is Fe, which has high levels during 2008 in all air samplers.

Concentrations of the elements $\mathrm{Pb}, \mathrm{Zn}, \mathrm{As}, \mathrm{Cd}, \mathrm{Fe}, \mathrm{Cu}, \mathrm{Mn}$ and the Mass Concentration of $\mathrm{PM}_{10}$ during 2008 vary widely. It is ascertained that during warm periods the levels of element and mass concentrations are generally higher (Papastamatiou, 2009). This variation can be explained due to high-speed winds, during warm periods and low precipitation, during a major part of the cold period ${ }^{1}$.

An effective way to determine the source of metallic minerals in the dust, are wind rose diagrams in connection with the concentrations of chemical elements. In Fig. 4 the average wind direction can

\footnotetext{
${ }^{1}$ Months from April to October are warm period, whereas November to March are cold period.
} 
Table 3. $\mathrm{Pb}$ concentration $\left(\mu \mathrm{g} / \mathrm{m}^{3}\right)$ in $\mathrm{PM}_{10}$ during 2008.

\begin{tabular}{|c|c|c|c|c|}
\hline Sampler & Max & Min & Average & Median \\
\hline SAM 1 & 1.116 & 0.029 & 0.356 & 0.257 \\
\hline SAM 2 & 0.404 & 0.057 & 0.184 & 0.167 \\
\hline SAM 3 & 0.114 & 0.013 & 0.063 & 0.062 \\
\hline
\end{tabular}

Table 4. Average metal concentration in $\mathrm{PM}_{10}$ during 2008

\begin{tabular}{|c|c|c|c|c|c|c|}
\hline & \multicolumn{6}{|c|}{ Average metal concentration $\left(\boldsymbol{\mu g} / \mathbf{m}^{3}\right)$} \\
\hline Sampler & $\boldsymbol{F e}$ & $\boldsymbol{A s}$ & $\mathbf{Z n}$ & $\boldsymbol{C} \boldsymbol{M}$ & $\boldsymbol{M n}$ & $\boldsymbol{C} \boldsymbol{d}$ \\
\hline SAM1 & 1.698 & 0.174 & 0.723 & 0.017 & 0.167 & 0.012 \\
\hline SAM2 & 1.604 & 0.08 & 1.178 & 0.017 & 0.036 & 0.011 \\
\hline SAM3 & 1.379 & 0.077 & 0.982 & 0.009 & 0.022 & 0.01 \\
\hline
\end{tabular}

Table 5. Average metal concentration in TSP during 1998-2000 (Gaidajis, 2003) Location of samplers: A. Close to fuel tanks, B. Close to Adit +410 .

\begin{tabular}{|c|c|c|c|c|c|c|}
\hline & \multicolumn{6}{|c|}{ Average metal concentration $\left(\boldsymbol{\mu g} / \mathbf{m}^{3}\right)$} \\
\hline Sampler & $\boldsymbol{F e}$ & $\boldsymbol{A s}$ & $\boldsymbol{Z n}$ & $\boldsymbol{C u}$ & $\boldsymbol{M n}$ & $\boldsymbol{C d}$ \\
\hline SAM 1 & 0.254 & 0.012 & 0.083 & 0.112 & 0.055 & 0.0006 \\
\hline A & 0.584 & 0.045 & 0.299 & 0.066 & 0.121 & 0.016 \\
\hline B & 0.247 & 0.019 & 0.051 & 0.041 & 0.103 & 0.0004 \\
\hline
\end{tabular}

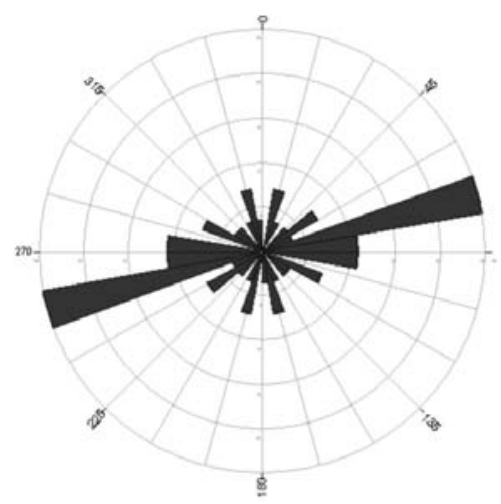

Fig. 4: Wind rose diagram during 2008 in Stratoni (Data from air sampler SAM 1).

be shown as a function of geographical bearings. The length of the bar for a particular direction indicates the time that the wind blows from that direction. It is concluded that the predominant wind direction is ENE and WSW.

Wind rose diagrams were also constructed based on wind data of air sampler SAM 1and elemental concentrations from chemical analysis of the filters of the same sampler (Fig. 5). The elements $\mathrm{Pb}$ and As have the highest concentrations when N-NE directed winds blow, indicating that the main source 

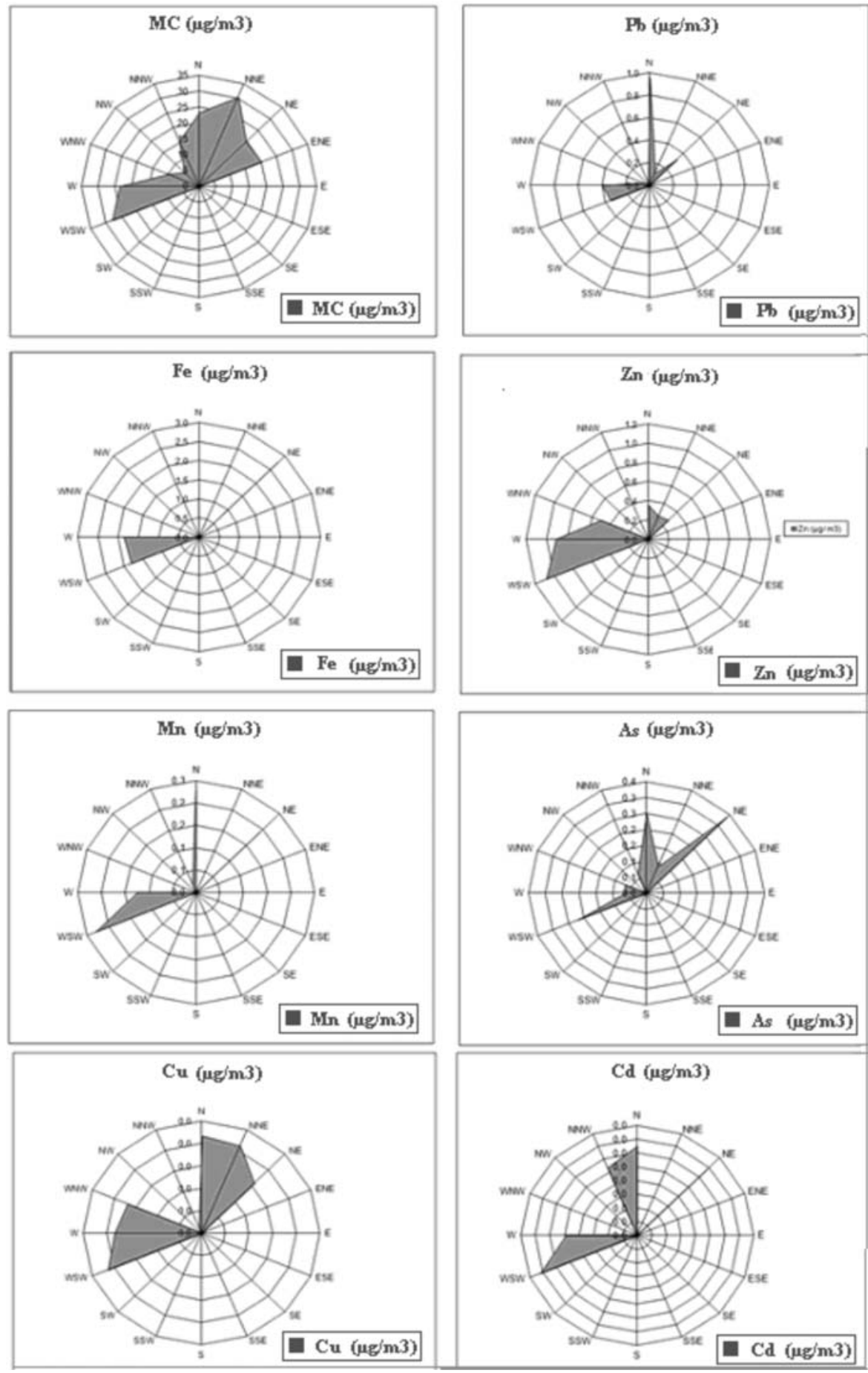

Fig. 5: Wind rose diagrams of $\mathrm{PM}_{10}, \mathrm{~Pb}, \mathrm{Fe}, \mathrm{Zn}, \mathrm{Mn}, \mathrm{As}, \mathrm{Cu}, \mathrm{Cd}\left(\mu \mathrm{g} / \mathrm{m}^{3}\right)$ (Data from sampler SAM 1). 
of these elements is dust that comes from the processing facilities located on this direction in relation to air sampler SAM1. Wind rose diagrams of Fe, Mn and $\mathrm{Zn}$ have high concentrations during WWSW winds. This observation suggests that the main source of the metal bearing particulate matter is the surface cover of the settlement of Stratoni. Data from previous studies, examining the composition of the soil from gardens of the settlement, confirmed that the main phases are oxides of $\mathrm{Fe}$ and Mn (Plakaki, 2006, Argyraki et al., 2007, Nicolaou, 2007). These mineral phases act as collectors for other metals. Finally, Mass Concentration, $\mathrm{Cu}$ and $\mathrm{Cd}$, present high concentrations both when NNE and WSW directed winds blow, suggesting a mixed source of the transported particulate matter.

\section{Conclusions}

Measurements of ambient concentrations of particulate matter of less than $10 \mu \mathrm{m}$ aerodynamic diameter $\left(\mathrm{PM}_{10}\right)$ are conducted on a 24 hours basis at Stratoni settlement. Evaluation of chemical data from air filters for the year 2008, combined with detailed mineralogical analysis of $\mathrm{PM}_{10}$ fraction leads to the following conclusions:

a. Mass Concentration of collected dust ranged between $2.5 \mu \mathrm{g} / \mathrm{m}^{3}$ and $79.6 \mu \mathrm{g} / \mathrm{m}^{3}$.

b. The majority of metal bearing dust grains are metallic minerals that exist in the ore. A mineralogical study of dust settled on filters in the air sampler operating close to the processing facility did not demonstrate variation in the type of metallic minerals. Galena, sphalerite and pyrite dominate, whereas bournotite, boulanzerite, chalcopyrite, cerussite, barite, gypsum, goethite and tennantite are subordinate mineral phases. During time periods when winds are of an E-NE direction it seems that seawater droplets are settled on the filters and halite is formed.

c. The annual limit value $\mathrm{PM}_{10}$ in all stations, as well as the $\mathrm{Pb}$ values are lower than the limits permitted by European Standards $\left(40 \mu \mathrm{g} / \mathrm{m}^{3}\right.$ and $0.5 \mu \mathrm{g} / \mathrm{m}^{3}$ respectively).

d. The number of exceedance days, that is the number of days when Mass Concentration exceeds the daily limit value of $50 \mu \mathrm{g} / \mathrm{m}^{3}$, is significantly lower than the number permitted by European Standards (35 days) ${ }^{2}$. It is worth mentioning that even at the station which is located very close to the processing facilities that number reached a value to 19 during the year 2008 .

e. On the basis of the EU Commission "Thematic Strategy on Air Pollution" published in 2005 the $\mathrm{PM}_{10}$ data at Stratoni pose no risk for human health. However, further research is needed before concluding on the safety of ambient air for the local population. To that end, examination of finer fractions of particulate matter (e.g. $\mathrm{PM}_{2.5}$ ) as well as collection of data from additional air samplers located within the area of the village of Stratoni is proposed.

${ }^{2}$ Consultation status in the EU on particulates provisions of the Air Quality Directive (from Goergen \& Lambrecht, 2007).

\begin{tabular}{|c|c|c|}
\hline & Commission proposal (09-09-05) & EP first reading (26-09-06) \\
\hline $\begin{array}{l}\text { Limit values } \\
\text { for PM10 }\end{array}$ & $\begin{array}{l}\text { a. Daily limit value from } 2005 \text { of } \\
50 \mu \mathrm{g} / \mathrm{m}^{3} \text {, which may be ex- } \\
\text { ceeded on a max. of } 35 \text { days } \\
\text { b. Annual limit value from } 2005 \\
\text { of } 40 \mu \mathrm{g} / \mathrm{m}^{3}\end{array}$ & $\begin{array}{l}\text { a. Daily limit value from } 2005 \text { of } 50 \mu \mathrm{g} / \mathrm{m}^{3} \text {, which may be } \\
\text { exceeded on a max. of } 35 \text { days, but possibility for mem- } \\
\text { ber States to increase the number of exceedance days to } \\
55 \text { from } 2010 \\
\text { b. Annual limit value from } 2005 \text { of } 40 \mu \mathrm{g} / \mathrm{m}^{3} \text { in the period } \\
\text { from } 2005-2010 \\
\text { c. Annual limit value of } 33 \mu \mathrm{g} / \mathrm{m}^{3} \text { from } 2010\end{array}$ \\
\hline
\end{tabular}




\section{Acknowledgments}

This research work would not had been possible without the support of "Hellenic Gold S.A.". Dr Emmy Gazea, Head of the Department of Environment and Safety of the Company, as well as D. Ballas, A.. Gatsios and E. Daftsis are thanked for providing help, for suggestions and discussions. We would like to thank Assoc. Prof. P. Nastos for helpful discussions, and an anonymous reviewer for critical comments which improved the manuscript.

\section{References}

Argyraki,A., Plakaki,A., Godelitsas, A., 2007. Characterization of garden soil pollution in the mining village of Stratoni, N. Greece. Bull. Geol. Soc. Greece, 40, 1331-1342.

Ballas, D. and Gazea, V., 2009. Measurements of $\mathrm{PM}_{10}$ in the area of Stratoni. Unpublished technical report, February 2009, Eurotechnica EPE, Chalkidiki, Greece.

Cooper, C.D., Alley, F.C., 2004. Air Pollution Control, A Design Approach, $3^{\text {rd }}$ edition, Waveland Press Inc., 739p.

DIRECTIVE 2008/50/EC of the European Parliament and of the Council of May 2008 on Ambient air quality and cleaner air for Europe. Official Journal of the European Union, 11-6-2008, L152/1-44.

Gaidajis, G., 2003. Ambient Concentrations of Total Suspended Particulate Matter and Its Elemental Constituents at the Wider Area of the Mining Facilities of TVX Hellas in Chalkidiki, Greece. Journal of Environmental Science and Health, A38, 10, 2509-2520.

Gilg, H.A., 1993. Geochronology (K-Ar), fluid inclusion, and stable isotope (C, H, O) studies of skarn, porphyry copper, and carbonate - hosted $\mathrm{Pb}-\mathrm{Zn}(\mathrm{Ag}, \mathrm{Au})$ replacement deposits in the Kassandra mining district (Eastern Chalkidiki, Greece). PhD Thesis, ETHZ, Zurich, 153p.

Gilg, H.A., Frei, R., 1994. Chronology of magmatism and mineralization in the Kassandra mining area, Greece: The potentials and limitations of dating hydrothermal illites, Geochemica et Cosmochimica Acta, 58, 9, 2107-2122.

Goergen, R., Lambrecht, U., 2007. Particulate Matter in Ambient Air. Journal for European Environmental \& Planning Law, 4, 4, 278-288.

Kockel, F., Mollat H., Walther H. W., 1977. Erlauterungen zur Geologischen Karte der Chalkidiki und angrenzender Gebiete 1:100.000 (Nord- Griechenland). Hannover, Bundesanstalt fur Geowissenschaften und Rohstoffe, 119p.

Nebel, M., Hutchinson R., Zartman, R., 1991. Metamorphism and polygenesis of the Madem Lakkos polymetalic sulfides deposit, Chalkidiki, Greece. Economic Geology, 86, 81-105.

Nikolaou, M., 1960. The Stratoni - Olympias granitic intrusion and the associated mineralization. Ann. Geol. Pays. Hellen., 2, 214-265.

Nikolaou, S., 2007. Spatial distribution of potentially toxic elements in soils at NE Chalkidiki, N. Greece. MSc Thesis, Department of Economic Geology \& Geochemistry, University of Athens, Athens, 168 p. (in Greek with English Abstract).

Papastamatiou, D., 2009. Inhalable particulate matter $\mathrm{PM}_{10}$ in mining areas: The case of Stratoni, Chalkidiki, Greece. MSc Thesis, Department of Economic Geology \& Geochemistry, University of Athens, Athens, 142p. (in Greek with English Abstract).

Plakaki, A., 2006. Mobility of potentially toxic elements in soils of the Stratoni mining area, Chalkidiki, N. Greece. MSc Thesis, Department of Economic Geology \& Geochemistry, University of Athens, Athens, 150 p. (in Greek with English Abstract ).

Plumlee G., Morman, S., Ziegler, T., 2006. The Toxicological Geochemistry of Earth Materials: An Overview of Processes and the Interdisciplinary Methods Used to Understand them. In: Sahai, N. \& 
Schoonen, M.A.A. (eds) Medical Mineralogy and Geochemistry. Mineralogical Society of America, Reviews in Mineralogy \& Geochemistry, 64, 5-57.

Posfai, M., Molnar, A., 2000. Aerosol particles in the troposphere: A mineralogical introduction. In: Vaughan, D.J. \& Wogelius, R.A. (eds). EMU Notes in Mineralogy, 2, Eoetvos University Press, Budapest, 197-252.

Skarpelis, N., Argyraki, A., Grypioti, A., 2009. Characterization of sources of inhalable particulate matter (PM10) in the old processing and smelting site of lavrion, Greece. Goldschmidt 2009, Davos, Swicherland, Special Supplement Geoch. et Cosmoch. Acta 73, no 13S, p. A 1324.

Triantafyllou, A., 2000. Patterns and concentrations of $\mathrm{PM}_{10}$ in a Mountainous Basin Region. Journal of the Air \& Waste Menagement Association, 50, 1017-1022.

Triantafyllou, A., Filippidis, A., Patra, A., Pavlidis, A., Kantiranis, N., 2000. Concentrations, mineralogy and morphology of the suspended particles $\mathrm{PM}_{10}$ in the city of Kozani. Proceedings $1^{\text {st }}$ Congress of the Committee of Economic Geology, Mineralogy and Geochemistry, Geological Society of Greece (Kozani), 452-462 (In Greek with English Abstract). 
